\title{
Study the Feasibility of Use of Grey Water in Concrete
}

\author{
Hawra Alradhawi ${ }^{1}$, Dr. S. S. Angalekar ${ }^{2}$ \\ ${ }^{1}$ Sinhgad College of Engineering, Pune, India \\ ${ }^{2}$ AssistantProfessor, Civil Engineering Department, Sinhgad College of Engineering, Pune, India
}

\begin{abstract}
Grey water is potentially less contaminated waste water. Taking scarcity of water into consideration various global agencies are suggesting reuse of grey water for different purposes. Water is one of the major ingredients of concrete and most used material in constructional practices. The grey water available from domestic sources is being used for gardening purpose. As discharge of grey water within the urban area is huge and as good as $60 \%$ of per capita domestic water supply. The possible use of Treated Grey Water for construction is investigated in our study. Samples of grey water are collected from various domestic sources and are subjected to aerobic treatment and then after they are tested to check their suitability for construction purpose. For this help was taken from environmental department in order to do suitable aerobic treatment to the grey water. Thus a method was devised by the environmental department for low cost aerobic treatment of sampled grey water. This becomes the base line for our project work as we received aerobically treated grey water from the environmental department which is further used for our comparisons with underground water. Both of them were found suitable for use in construction purpose. Investigation is then carried out to study the comparative effect of both water samples on the strength of concrete. Concrete cubes of grades M-25 were cast using Under Ground Water (UGW) and Treated Grey Water (TGW) and tested for various tests. The comparative results of tests on concrete were found to be almost similar.
\end{abstract}

Keywords: concrete, treated grey water TGW, underground water UGW

\section{Introduction}

Water is the foundation of life. And still today, all around the world, far too many people spend their entire day searching for it. Clean, safe drinking water is scarce. Today, nearly 1 billion people in the developing world don't have access to it. Yet, we take it for granted, we waste it, and we even pay too much to drink it from little plastic bottles. The motivations for recycling are manifold and can include water shortage caused by either low rainfall or excessive demand, environmental and economic drivers.

Concrete has been the most widely used construction material due to its mould-ability in the fresh state, and durability over a long period. Water and concrete are the two materials most used by mankind: water in the first place and concrete in the second. There is an increasing demand for concrete for infrastructural developments all over the world. Water is one of the major ingredients of concrete when hydraulic cement is used. Each gram of cement of average composition needs about $0.253 \mathrm{~g}$ of water for hydration. Water is also needed for imparting workability and also for curing. The requirements to be satisfied by water for the use in concrete are specified in various codes. Mostly all the codes specify that the potable water can be satisfactorily used for making concrete. It means that construction industry demands huge quantity of potable water which is becoming scarce day by day. India is already on the brink of entering the list of water stressed countries. In India, with around $17 \%$ of the world's population, it has only $4 \%$ potable water. Recently many Countries, States and Organizations are trying to propagate the use of treated grey water for irrigation, gardening, washing etc. Considering the quantum of population and construction in India, grey water may become a continuous and potential source of water.

\section{Scope of this Study}

The nature of the wastewater and in particular its high organic strength direct the selection of appropriate processes towards biological systems. Thus the decision of treatment systems was done by the environment lab as a separate project and we followed it up by checking the suitability of that treated Grey Water in concrete preparation.

The broad objective for Treated Grey Water to be used in concrete preparation was that the concrete must be defined on the basis of mechanical and durability properties. To define this, tests such as compressive strength, flexural strength, permeability and RCPT were done to compare critical factors of performance.

\section{Literature Review}

Rajesh T. Peche, Dr. Sanjay S. Jamkar based on their study of Influence of Grey Water as Mixing Water on Properties and Strength of Cement conducted at Department of Applied Mechanics, Government College of Engineering, Aurangabad, India concluded that considering huge and perennial availability, grey water has a potential to fight against scarcity of water. The types of grey water used, met the standards of mixing water as mentioned in various codes. Grey water should be disinfected before use to avoid health risks to people at work. Compared with tap water lesser amount of grey water is required to achieve Standard Consistency of cement. Soundness of Grey water mixed cement paste is almost same to the tap water cement paste. Grey water reduces the initial and final setting time but that reduction is marginal and still within the prescribed limits. Cement mixed with Grey water has more compressive strength than the cement mixed with tap water. Increase in 


\section{International Journal of Science and Research (IJSR) \\ ISSN (Online): 2319-7064}

Index Copernicus Value (2013): 6.14 | Impact Factor (2015): 6.391

compressive strength may be due to the presence of higher soaps, detergents and surfactants in grey water.

\begin{abstract}
Abdul Razak .B .H, Dr. D. L. Venkatesh concluded that, there is a decrease in the workability of concrete using primary treated water whereas secondary treated water gave better workability to concrete. There is no significant difference in the compressive strength value of concrete made using primary treated-water, secondary treated water and potable water. The tensile strength of concrete made using sewage treated water was found to be lesser compared to that of potable water. Considerable construction cost can be reduced by utilizing the treated water for plain cement concrete. Concrete made using sewage treated water showed good fresh and hardened properties. Hence its usage can be beneficial for the concrete industry in terms of cost saving. Usage of sewage-treated water is most suitable for sustainable development. Potable water can be saved to a great extent. Concrete made using sewage treated water is more suitable for plain concrete as there are possibilities of corrosion of reinforcement due to the organic and inorganic impurities present in the sewage-treated water. Further research on usage of sewage treated water for production of reinforced cement concrete can be carried out by studying the corrosion of reinforcement.
\end{abstract}

\section{Need of Study}

To conduct a feasibility study of using treated grey water in concrete production, assess the durability of concrete made with grey water by the durability tests Acid Attack, Water Permeability, Chloride Attack and Sea Water Checked by doing RCPT and determine mechanical properties of concrete (compressive, tensile and flexural strength of concrete mixtures).

\section{Materials}

\subsection{Cement}

We have chosen Ultratech Cement 53 Grade is selected. Ultratech cement of week no. 4 and month. 1 and year.2016, it was tested as per IS:4031 Fine aggregate.

These are material passing through an IS sieve that is less than $4.75 \mathrm{~mm}$ gauge beyond which they are known as coarse aggregate. Coarse aggregate form the main matrix of the concrete, whereas fine aggregate form the filler matrix between the coarse aggregate. The most important function of the fine aggregate is to provide workability and uniformity in the mixture. The fine aggregate also helps the cement paste to hold the coarse aggregate particle in suspension.

\subsection{Coarse Aggregates}

The general size of coarse aggregate is $10 \mathrm{~mm}$ and $20 \mathrm{~mm}$. The important parameters of coarse aggregate that influence the performance of concrete are its shape, texture and the maximum size. Since the aggregate is generally stronger than the paste, its strength is not a major factor for normal strength concrete, or for HES and VES concretes.
However, the aggregate strength becomes important in the case of high performance concrete.

\subsection{Water}

Two types of water were chosen for this study and both the sources were checked as pre the testing procedures of IS: 3025 and checked for permissible limits as per I.S.456 2000 regarding water for Mixing and Curing.

I) UGW - Underground water, sourced from Wagholi village Pune.

II) TGW - Treated Grey water, sourced from STES staff quarters at Ambegaon, Pune

Water samples were tested as per IS: 3025 and limits as per IS: 456

\subsection{Admixture}

BASF Master Rheobuild 8501 was used to produce M25 grade of concrete.

\section{Experimental Work}

In the experimental program, three basic tests for mechanical properties of concrete were conducted i.e. tests for compressive strength, flexural strength and split tensile strength. The mechanical properties of concrete were tested at the various ages. The compressive strength was tested on concrete cubes of $150 \times 150 \times 150 \mathrm{~mm}$ after water curing for 3 days, 7 days, 14 days, 28 days and 56 days. The flexural strength was tested using concrete beams with dimension of $150 \times 700 \times 700 \mathrm{~mm}$ after curing in the water for 28 days. The split tensile strength was tested using concrete cylinders with dimension $\varphi 150 \mathrm{~mm} \times 300 \mathrm{~mm}$ after curing in the water for 28 days. Besides those strength tests of the concrete, the durability tests of concrete were also conducted which consisted of rapid chloride penetration test and permeability test.

\subsection{Compressive Strength Test}

The compression test was conducted as per IS 516. The specimens were kept in water for curing for 7 days, 14 days, 28 days and 56 days and on removal were tested in dry condition and grit present on the surface. The load was applied without shock and increased continuously at a rate of approximately $140 \mathrm{~kg} / \mathrm{sq}$. $\mathrm{cm} / \mathrm{min}$ until the resistance of the specimen to the increasing load breaks down and no greater load can be sustained. The maximum load applied to the specimen was then recorded and the appearance of the concrete for any unusual features in the type of failure was noted. 


\section{International Journal of Science and Research (IJSR) \\ ISSN (Online): 2319-7064}

Index Copernicus Value (2013): 6.14 | Impact Factor (2015): 6.391

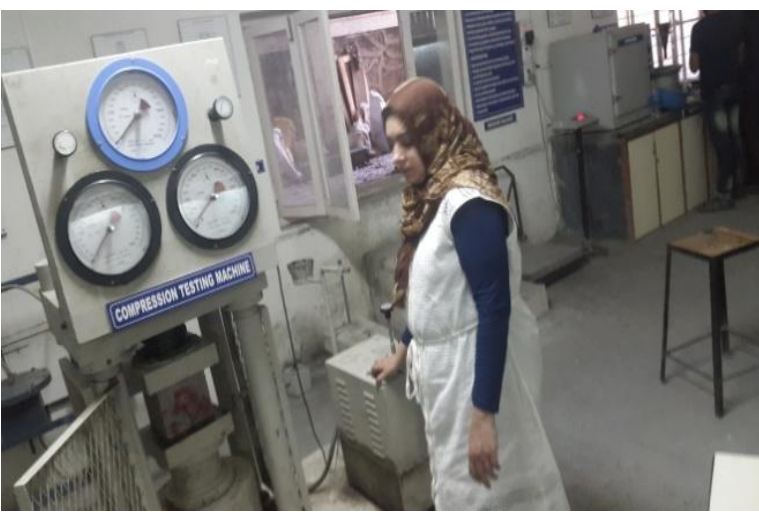

Figure 1: Cube Testing on a Compression Testing Machine

\subsection{Flexural Strength}

The bed of the testing machine shall be provided with two steel rollers, $38 \mathrm{~mm}$ in diameter, on which the specimen is to be supported, and these rollers shall be so mounted that the distance from centre to centre is $60 \mathrm{~cm}$ for $15.0 \mathrm{~cm}$ specimens. The load shall be applied through two similar rollers mounted at the third points of the supporting span that is, spaced at $20 \mathrm{~cm}$ centre to centre. The load shall be divided equally between the two loading rollers, and all rollers shall be mounted in such a manner that the load is applied axially and without subjecting the specimen to any torsional stresses or restraints.

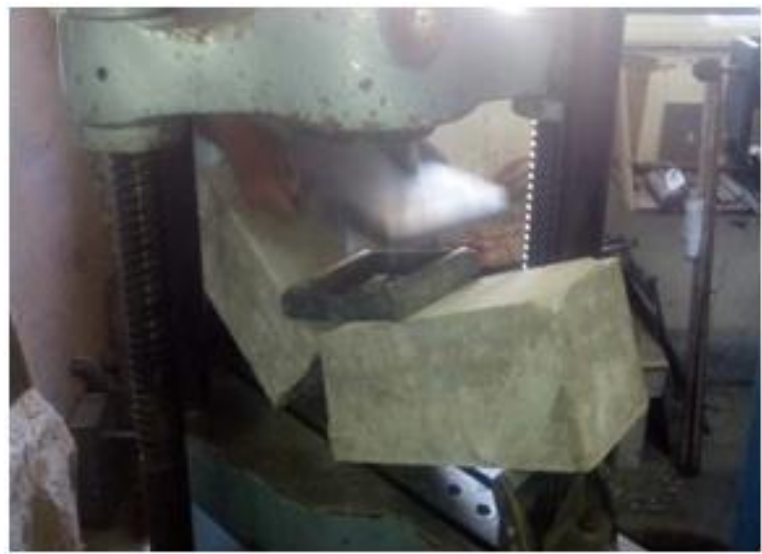

Figure 2: Flexure Beam Failure (Regular beam without any reinforcement)

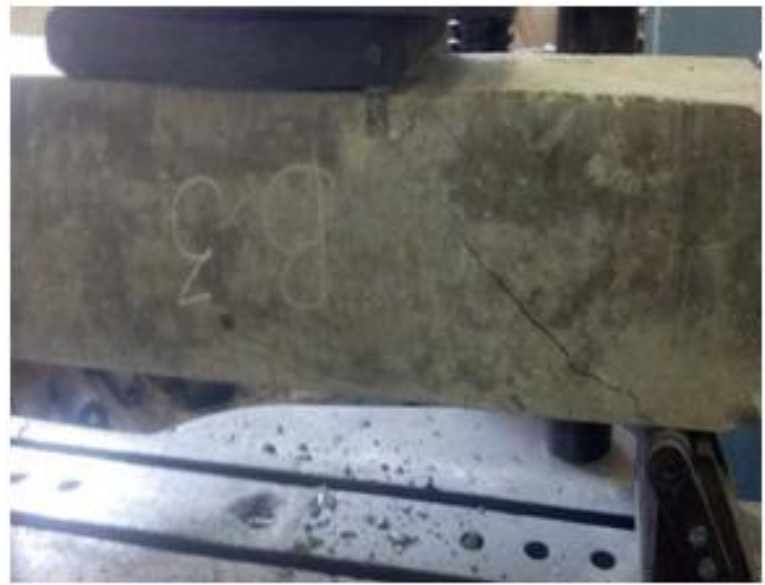

Figure 3: Diagonal Crack in Reinforced Beam

\subsection{Splitting Tensile Test}

The split tensile test were conducted as per IS 5816. The size of cylinder is $300 \mathrm{~mm}$ length with $150 \mathrm{~mm}$ diameter. The specimen were kept in water for curing for 28 days and on removal were tested in wet condition by wiping water and grit present on the surface.

The test is carried out by placing a cylindrical specimen horizontally between the loading surfaces of a compression testing machine and the load is applied until failure of the cylinder along the vertical diameter. The maximum load applied to the specimen.

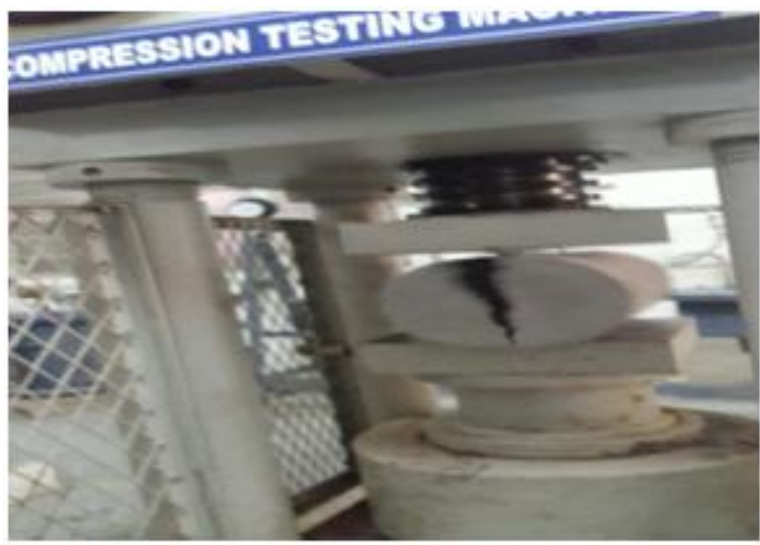

Figure 4: Loading in Progress of cylinder

\subsection{Acid Attack}

For this test, 3 cubes each from the two mixes were immersed in $3.33 \%$ concentrated solution having init ial concentration of $30 \%$.

Thus the effective concentration of the acid solution was $1 \%$ as a whole. These cubes were cured continuously in the acid solution and the weights were checked after 28 and 56 days.

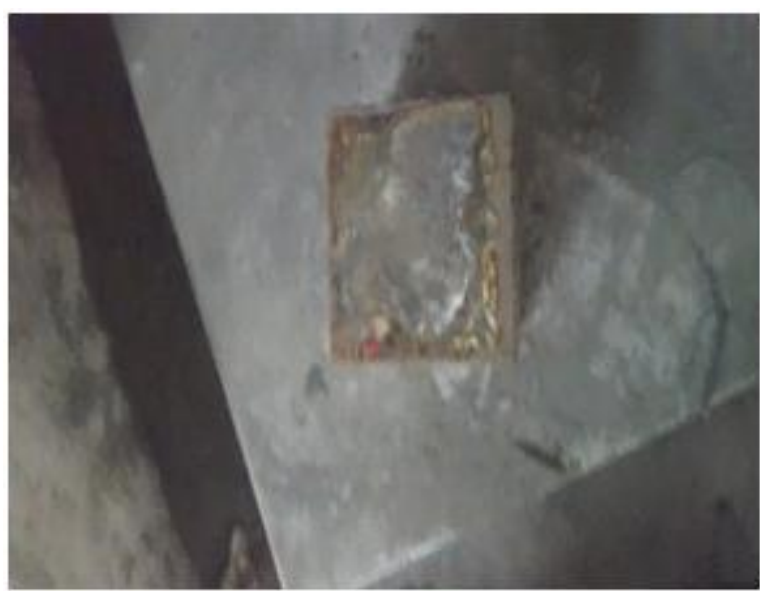

Figure 5: Cube condition after 56 days of acid attack

\subsection{Water Permeability}

The test is carried out according to German Standard DIN 1048 on concrete specimens of size $150 \times 150 \times 150 \mathrm{~mm}$, at an age of 28 days. The test cell assembly being used had the provision for testing three / six cubes at a time.

Volume 5 Issue 6, June 2016 www.ijsr.net 


\section{International Journal of Science and Research (IJSR) \\ ISSN (Online): 2319-7064}

Index Copernicus Value (2013): 6.14 | Impact Factor (2015): 6.391

Once the specimens were assembled in the test cells, a water pressure of $500 \mathrm{KPa}$ (5 bar) was applied for 72 hours. Water pressure is applied by means of an arrangement consisting of a water tank connected to an air compressor through a valve, to adjust the pressure.

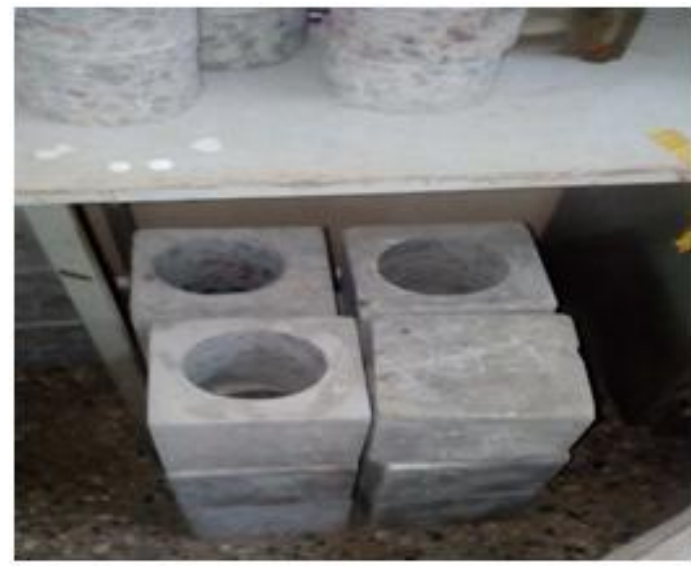

Figure 6: Applied pressure on cube

\subsection{Rapid Chloride Penetration Test (RCPT)}

The test method involves obtaining a $100 \mathrm{~mm}$ diameter core or cylinder sample from the concrete being tested. A $50 \mathrm{~mm}$ specimen is cut from the sample. The side of the cylindrical specimen is coated with epoxy, and after the epoxy is dried, it is put in a vacuum chamber for 3 hours. The specimen is vacuum saturated for 1 hour and allowed to soak for 18 hours. It is then placed in the test device (see test method for schematic of device). The left-hand side $(-)$ of the test cell is filled with a $3 \% \mathrm{NaCl}$ solution. The right- hand side (+) ofthe test cell is filled with $0.3 \mathrm{~N}$ $\mathrm{NaOH}$ solution. The system is then connected and a 60volt potential is applied for 6 hours. Readings are taken every 30 minutes. At the end of 6 hours the sample is removed from the cell and the amount of coulombs passed through the specimen is calculated.

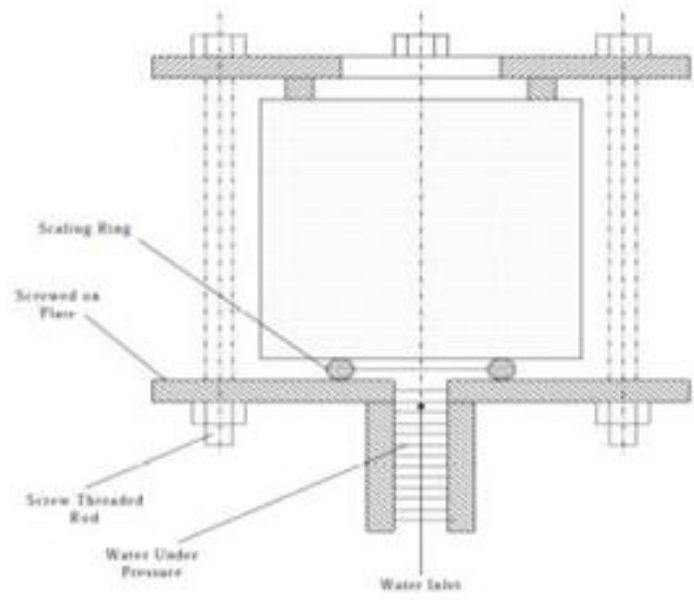

Figure 7: Sample Preparation by making a core in the cube

\section{Results}

\subsection{Compressive Strength Test}

The compression test was conducted as per IS 516. The specimens were kept in water for curing for 7 days, 14 days, 28 days and 56 days and on removal were tested in dry condition and grit present on the surface. The load was applied without shock and increased continuously at a rate of approximately $140 \mathrm{~kg} / \mathrm{sq} . \mathrm{cm} / \mathrm{min}$ until the resistance of the specimen to the increasing load breaks down and no greater load can be sustained. The maximum load applied to the specimen was then recorded and the appearance of the concrete for any unusual features in the type of failure was noted. Average of three values was taken as the representatives of the compressive strength of the sample as noted. Experimental set up for compressive strength testing there is a benefit of having concrete with a compressive strength in excess of the design strength. While maintaining a compressive strength of M 25 provides adequate strength, higher strength concrete can easily be proportioned. The benefits produced in other performance criteria as a result of this increased strength are almost essential. A constant rate of loading was maintained throughout, within the tolerances of the testing machine, and the rate was within the limits provided in IS: 516. Ultimate compressive stress was recorded. Observations and calculations were made to check whether all 3 cube results are within the $\pm 15 \%$ of the average cube strength.

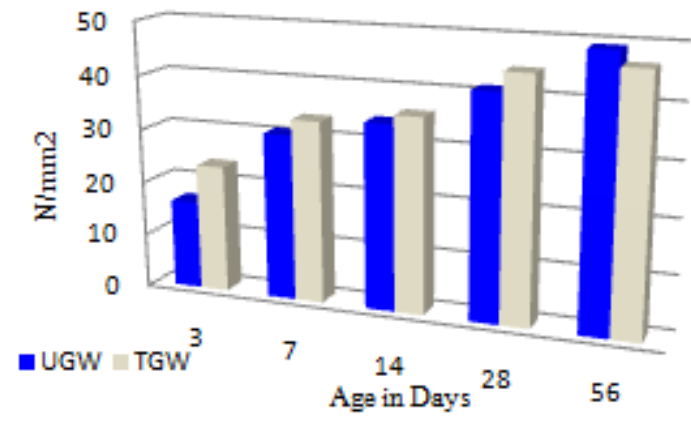

Figure 8: Average Compressive Strength

\subsection{Flexural Strength}

The UGW is clearly ahead of TGW and in both the Flexure strength as well as the RCC diagonal crack case.

While comparing the Flexure strength there is a difference of $1.9 \%$. Considering this we can assume that the both the mixes will perform almost similarly.

But when the reinforced beams are subjected to the loads till the appearance of first crack, the load taken by UGW is more than TGW by $6.5 \%$ and this is a big leap. Though we can think that the higher alkalinity can help in initial prevention of corrosion of the reinforced steel but in the longer duration as there will be more ingress of cracks thus TGW will be more prone to corrosion problems. 
International Journal of Science and Research (IJSR)

ISSN (Online): 2319-7064

Index Copernicus Value (2013): 6.14 | Impact Factor (2015): 6.391

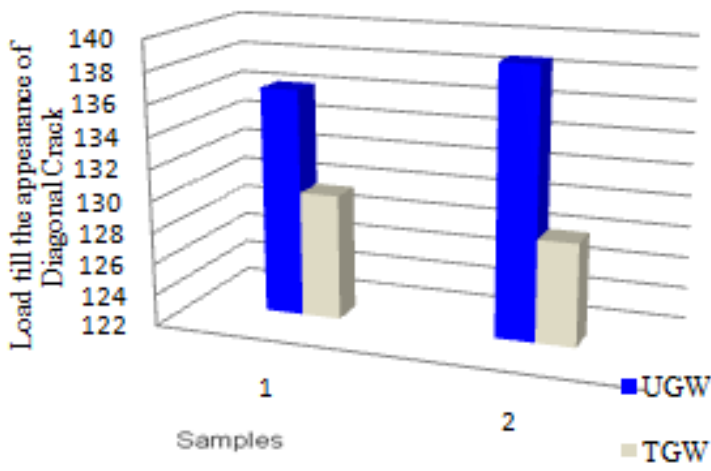

Figure 9: Average Flexure Strength

\subsection{Splitting Tensile}

The functioning of TGW is a much better than $\mathrm{UGW}$ at the 28 day age.

As splitting tensile is a very handy indicator of tension taking capacity of concrete and much of the correlation of tensile strength with respect to the compressive strength is done on the basis of splitting tensile strength thus it becomes a major guideline.

Again here we observe very less difference owing to which we can say that TGW can be used as a successful replacement to the scarce UGW.

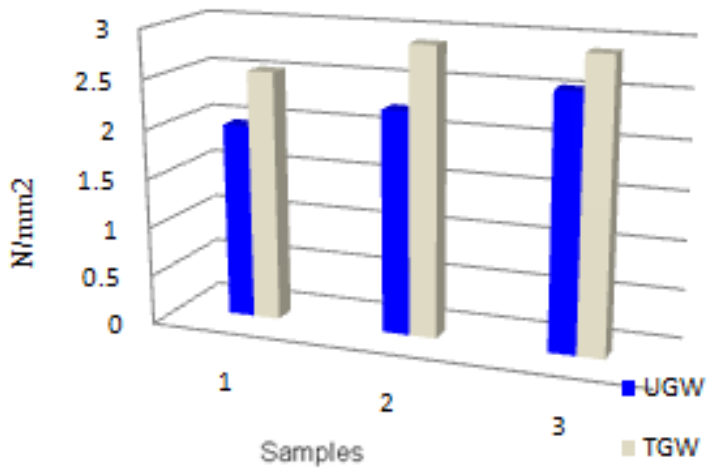

Figure 10: Average Splitting Tensile

\subsection{Acid Attack}

This is one of the most significant result observations in our overall project work. There is a noticeable difference between both the mixes and the same pattern is observed at 28 days and 56 days also. If we look at the percentage loss of weight it is observed to be less than $1.5 \%$ for all 4 result cases showing that there is not much loss and both the mixes are good and strong enough to handle a fair enough acid attack..But when we sit back and compare the UGW to TGW there is a stark difference and TGW results are lower by $25 \%$ at 28 days and by $30 \%$ at 56 days. This clearly highlights that the comparative capacity to handle acid for TGW is significantly less than compared to UGW and hence while designing concrete for an acid attack environment it will be necessary to choose the UGW option.

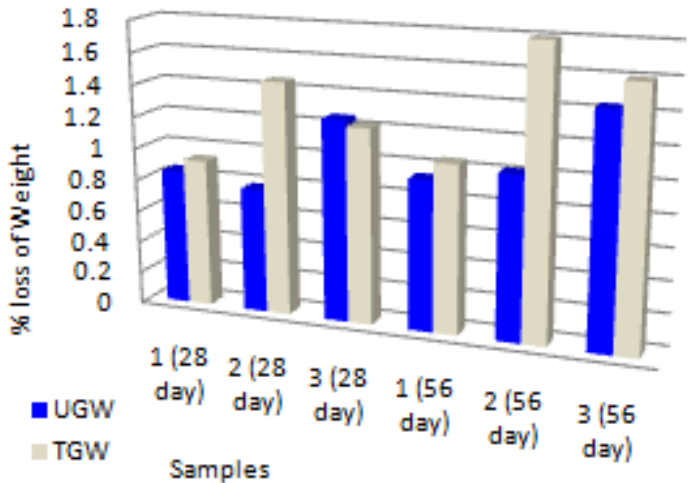

Figure 11: Acid Attack

\subsection{Water Permeability}

Water permeability can be directly linked to the porosity structure of the mix and thus we can state that the porosity of the TGW mixes are more due to induced higher acidity.

This can again prevent the use of TGW in high value or high stress structures as it may have adverse effect on the steel corrosion owing to the high porosity and water permeability. At Low pressures the difference is alarming 91\% more than UGW. Even at High pressure it is $10 \%$ more than UGW. The results clearly indicate that use of TGW should be avoided in water retaining structures where the ingress of water can be attributed more towards the low pressure criteria and hence there can be higher ingress leading to catastropical issues regarding the corrosion of steel. As water is the vehicle for many other chemicals to reach deep inside the concrete and disturb it from within. Also it can trigger the internal porosity and disturb not only the cover concrete but also the core concrete.

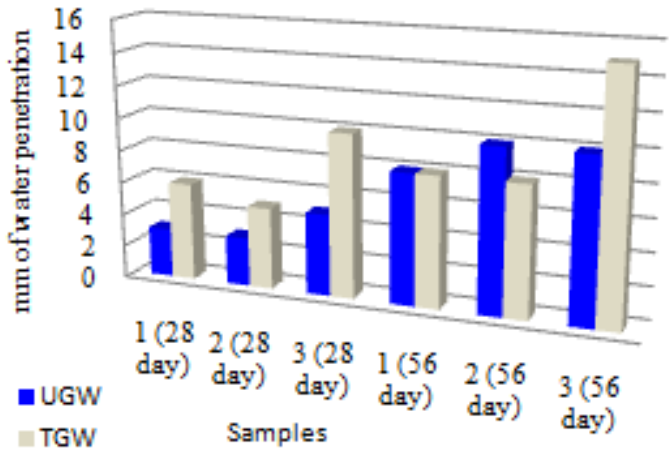

Figure 12: Average Water Permeability

\subsection{RCPT}

As of now on international level RCPT is a widely accepted test procedure to prove the durability parameters of concrete. The results of RCPT are interesting as we see that all of the concrete comes in to the category of low chloride permeability but all results are at the border line and linger around just below the 2000 coulombs mark. Thus it is not very happy situation. When we look into the comparative results we strength results the TGW is better placed than the UGW and this result reinstates faith in using TGW in the cases of coastal and sea water construction. The percentage difference between the

Volume 5 Issue 6, June 2016 www.ijsr.net 


\section{International Journal of Science and Research (IJSR) \\ ISSN (Online): 2319-7064}

Index Copernicus Value (2013): 6.14 | Impact Factor (2015): 6.391

comparative results shows that the difference in all 3 cases is less than $2 \%$ which can be considered to be insignificant as the readings are in the range of 2000 coulombs. In the normal category only the UGW is performing better than the TGW. These results can have a long standing effect in acceptability of TGW in the construction works as it seriously stamps its performance.

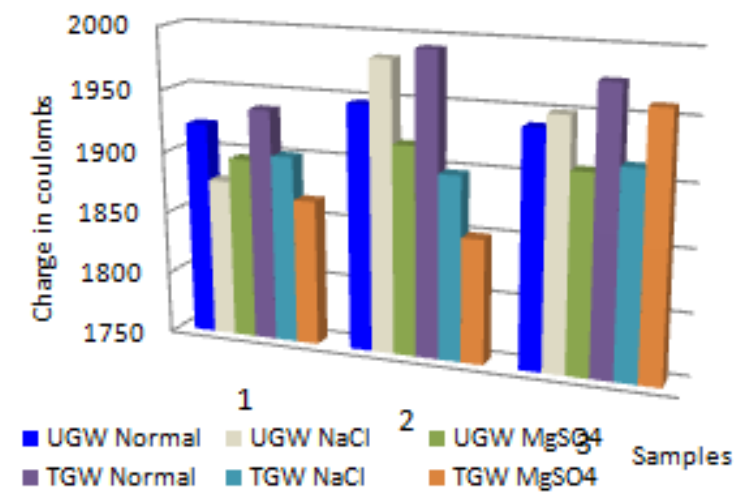

Figure 13: Average RCPT

\section{Conclusion}

1. The one major observational difference between UGW and TGW is that the TGW even after aerobic treatment has higher alkalinity as well as acidity as compared to UGW.

2. Owing to these major differences the properties of concrete made from TGW can be affected in the long time.

3. Flexural strength is a very important characteristic of concrete as it defines the usability of concrete in road pavements. Road pavements are more often without any reinforcement, thus providing an added advantage for TGW to be used in it. Pavement quality concrete (PQC) is often expected also to be durable and of high strength.

4. The most significant observation being that by further working on the treatment processes TGW can be made less alkaline and less acidic.

5. In the current work done the TGW is at the receiving end while the UGW is faring better except in the RCPT.

6. Overall it may be seen such that the porosity of the TGW has increased and can further increase if there is exposure of core concrete to either water or carbon dioxide which may enter the TGW owing to its surface porosity and water permeability.

7. The acid attack figure also cripples TGW but when we look at both the results individually we find that they are very low, only in case of comparative observation the results tend to be more in favour of UGW.

8. The compressive strength results are a kind of reprieve for TGW and it was constantly ahead of it till 28 days showing that it has potential to absorb a secondary cementitious additive in the form of flyash or slag. The overall condition of TGW in our study work is favourable for these additives as they may get a ready reactive field and thus give better early strengths.

9. The concluding remark would touch upon the point that we should start using TGW from this date only at mass scale level this will help in bringing appropriate talent in to the water cleaning services and as a counter effect we can get much better TGW having no residual effect on concrete.

\section{References}

[1] K.J.Kucche, Dr.S.S.Jamkar, Dr.P.A.S adgir "Quality of water for making concrete: A review of Literature", International Journal of Scientific and research publications. (2015), International Research Journal of Engineering and Technology (IRJET) e- ISSN: 2395-0056 Volume: 02 Issue: 08 | Nov-2015 www.irjet.net p-ISSN: 2395-0072

[2] Abdul Razak.B.H, Dr.D.L.Venkatesh Babu "Experimental investigation on usage of grey water in concrete production", International Journal of Scientific and research publications. (2015), International Research Journal of Engineering and Technology (IRJET) e-ISSN: 2395-0056 Volume: 02 Issue: 08 | Nov-2015 www.irjet.net p-ISSN: 2395-0072 @ 2015, IRJET ISO 9001:2008 Certified Journal Page 783

[3] Marcia Silva and Tarun R.Naik, "Sustainable use of resources-Recycling of Sewage treatment plant water in concrete", Second international conference on sustainable construction materials and Technologies, (2010)

[4] BS EN 1008, Mixing water for concrete Specification for sampling, testing and assessing the suitability of water, including water recovered from processes in the concrete industry, as mixing water for concrete, British standard, 2002

[5] G.L.Low, K.Y.Ng, W.L.Ng, C.T.Tam, R.B.W.Heng, " Use of Recycled cement based slurry water for making concrete", Journal of The Institution of Engineers, Malaysia, (2007)

[6] Rickert.J and Grube.H, "Influence of recycled water from fresh concrete recycling systems on the properties of fresh and hardened concrete", VDZ, Concrete Technology Reports. Dusseldorf, Germany. (2003)

[7] Chini.S.A and Mbwambo.W.J "Environmentally friendly solutions for the disposal of concrete wash water from ready mix concrete operations", in Proceedings of CIB W89 Beijing International Conference, (1996)

[8] Cebeci.O.Z \& Saatci.A.M, "Domestic sewage as mixing water in concrete", ACI Materials Journal, 86(5):503-5066

[9] AASHTO T277, - Standard Method of Test for Rapid Determination of the Chloride Permeability of Concretel

[10]ACI Committee 116, (1967) "Cement and Concrete Terminology, " Publication SP-19, pp. 24 